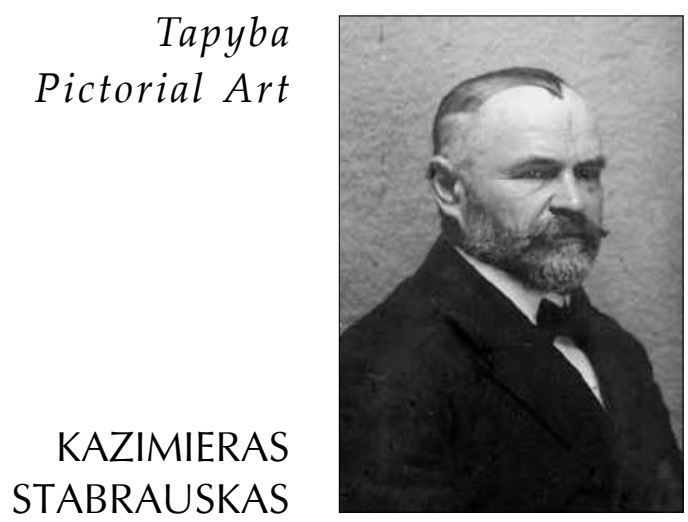

\title{
DAILININKAS KAZIMIERAS STABRAUSKAS
}

Dailininkas KAZIMIERAS STABRAUSKAS (KAZIMIERZ STABROWSKI, 1869-1929) gimė Gardino gubernijoje Kruplianuose, netoli Naugarduko, dvarininkų šeimoje. Baigęs Balstogès realinę gimnaziją 1887-1894 m. studijavo Sankt Peterburgo dailès akademijoje, 1894-1897 m. tobulinosi Iljos Repino studijoje, 1897 m. tęsė studijas Juliano akademijoje Paryžiuje. Dailininkas keliavo po Artimųų Rytų šalis Turkiją, Libaną, Siriją, Palestiną, Egiptą, Tunisą, dažnai lankèsi pagrindiniuose Vakarų Europos kultūros centruose. 1903 m. apsigyveno Varšuvoje, čia 1904 m. įūrè Varšuvos dailès mokyklą ir iki 1909 m. jai vadovavo, artimai bendravo su "Jaunosios Lenkijos" (Młoda Polska) sąjūdžio nariais, dėstė M. K. Čiurlioniui, aktyviai skelbė teosofijos ir okultizmo idėjas, rèmé lietuvių dailininkų parodų idèją. 1907-1912 m. kartu su iš Kauno kilusia žmona skulptore Julija dalyvavo pirmose šešiose Lietuvių dailès draugijos parodose. Nutapè daug peizažų, fantastinių vizijų, figūrinių kompozicijų, daugiausia - svajingų moterų portretų. Kūrybai būdinga simbolizmo, neoromantizmo, impresionizmo, modernizmo bruožai, fantastinè, alegorinè tematika, ekspresyvumas ir slèpiningumu dvelkianti ezoterinė simbolika.

\section{Painter Kazimieras Stabrauskas}

The artist KAZIMIERAS STABRAUSKAS (Polish: KAZIMIERZ STABROWSKI, 1869-1929) was born in a landlord's from Naugardukas family, in Kruplian, the Province of Grodno. After graduating from Białystok Real Gymnasium, he studied at the St. Petersburg Academy of Arts in 1887-1894. In 1894-1897, he continued his studies in Ilya Repin's studio. In 1897, he studied at Julian Academy in Paris. He traveled to the countries of the Middle East including Turkey, Lebanon, Syria, Palestine, Egypt, Tunisia. He also often visited the main cultural centers in the Western Europe. In 1903, he settled in Warsaw, where in 1904 he established the Warsaw School of Arts and headed it until 1909. During this period he closely cooperated with the members of the Young Poland (Młoda Polska) Movement, lectured to Mikalojus Konstantinas Čiurlionis, published articles on theosophy and occultism, promoted the idea of the Lithuanian art exhibitions. In 1907-1912, together with his wife Julia (who was born in Kaunas) he took part in the first six Lithuanian Art Society exhibitions. He painted a lot of landscapes, fantasies, figural compositions, and many portraits of starry-eyed women. The characteristic features of his works display symbolism, neoromanticism, impressionism, modernity, fiction, allegory, expressiveness, and esotery, tinted with mystery.

RAKTAŽODŽIAI: Kazimieras Stabrauskas, tapyba, teosofija, simbolizmas, neoromantizmas.

KEY WORDS: Kazimieras Stabrauskas, painting, theosophy, symbolism, neo-romanticism. 


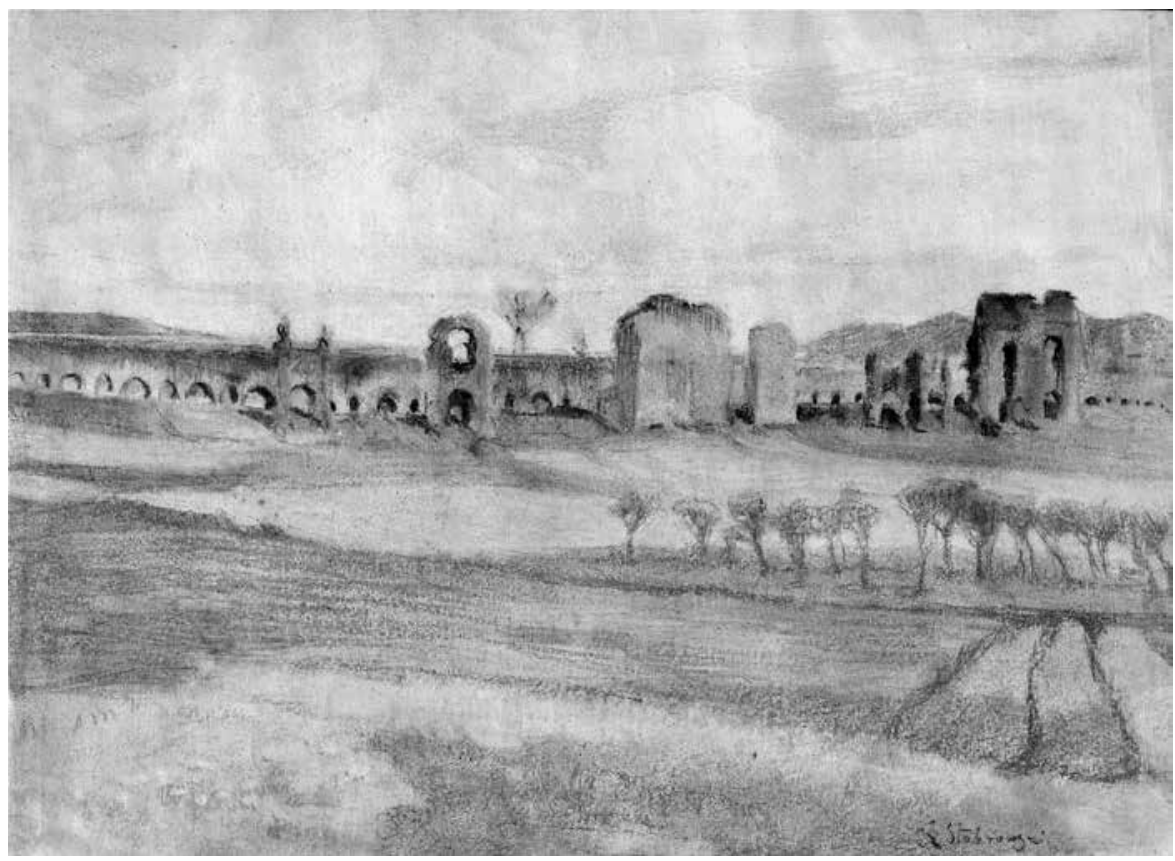

Kazimieras STABRAUSKAS. Pilies griuvėsiai. XX a. pr. Popierius, pastelè. $47 \times 67$ Dr. Jauniaus Gumbio kolekcija

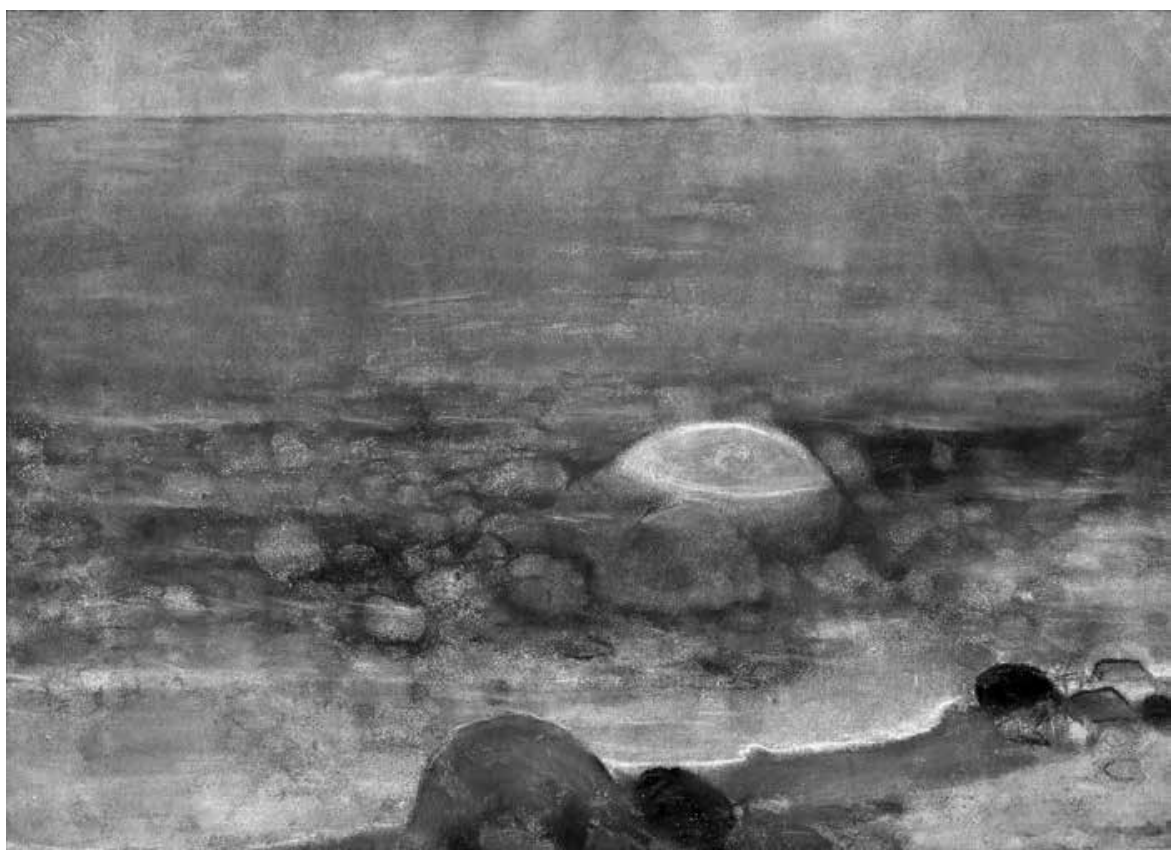

Kazimieras STABRAUSKAS. Jūros krantas. XX a. pr. Popierius, pastelè. $71 \times 88$ Dr. Jauniaus Gumbio kolekcija 


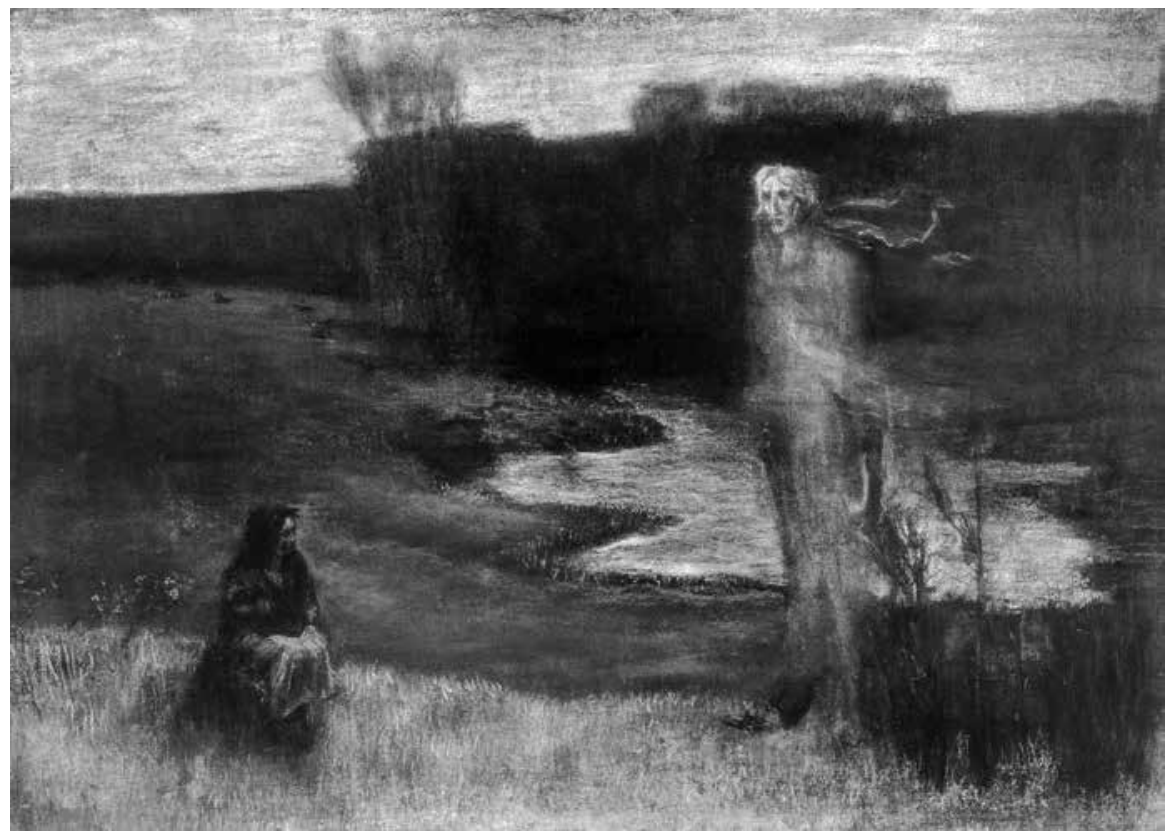

Kazimieras STABRAUSKAS. Mirties šmèkla. 1907. Popierius, pastelè. $50 \times 70$ Dr. Jauniaus Gumbio kolekcija

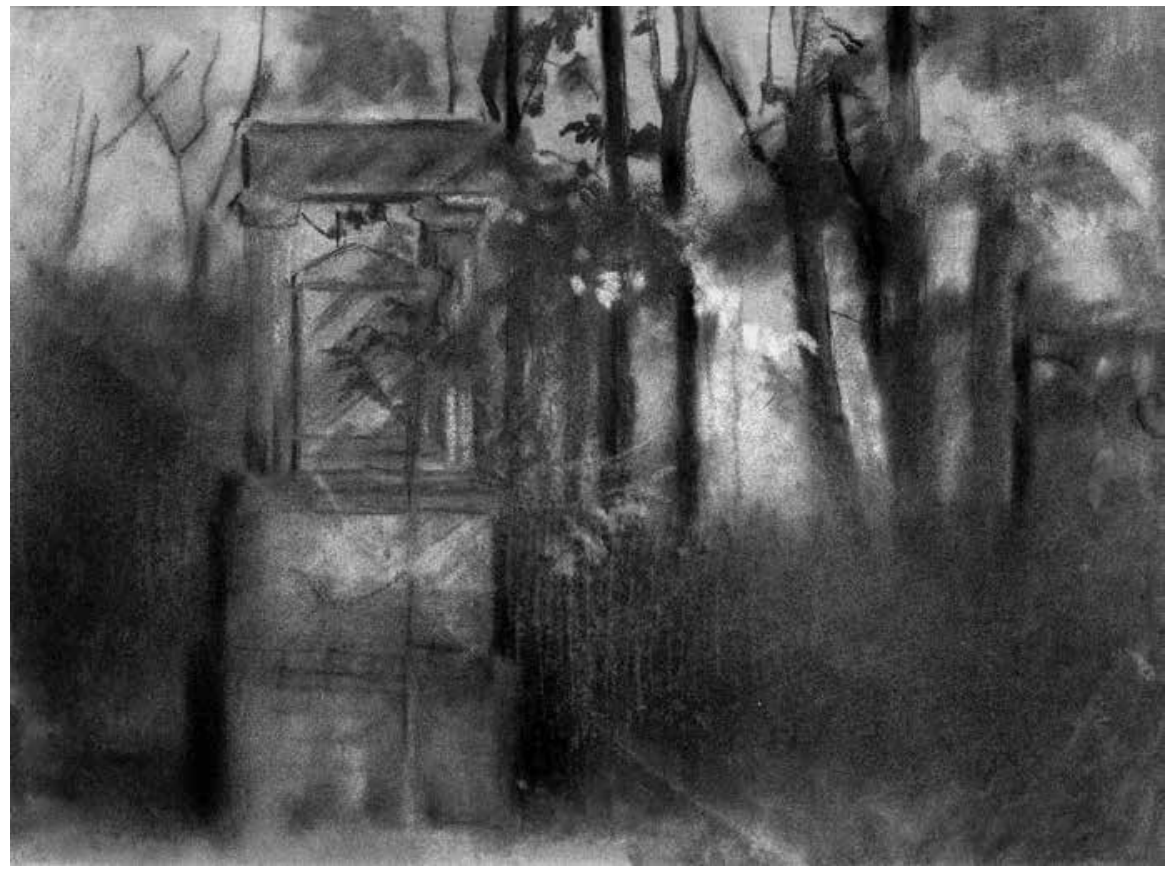

Kazimieras STABRAUSKAS. Kapas tarp medžių. 1900-1910. Popierius, pastelè. 47,5 × 85 Iš "Lietuvos meno pažinimo centro Tartle" kolekcijos 


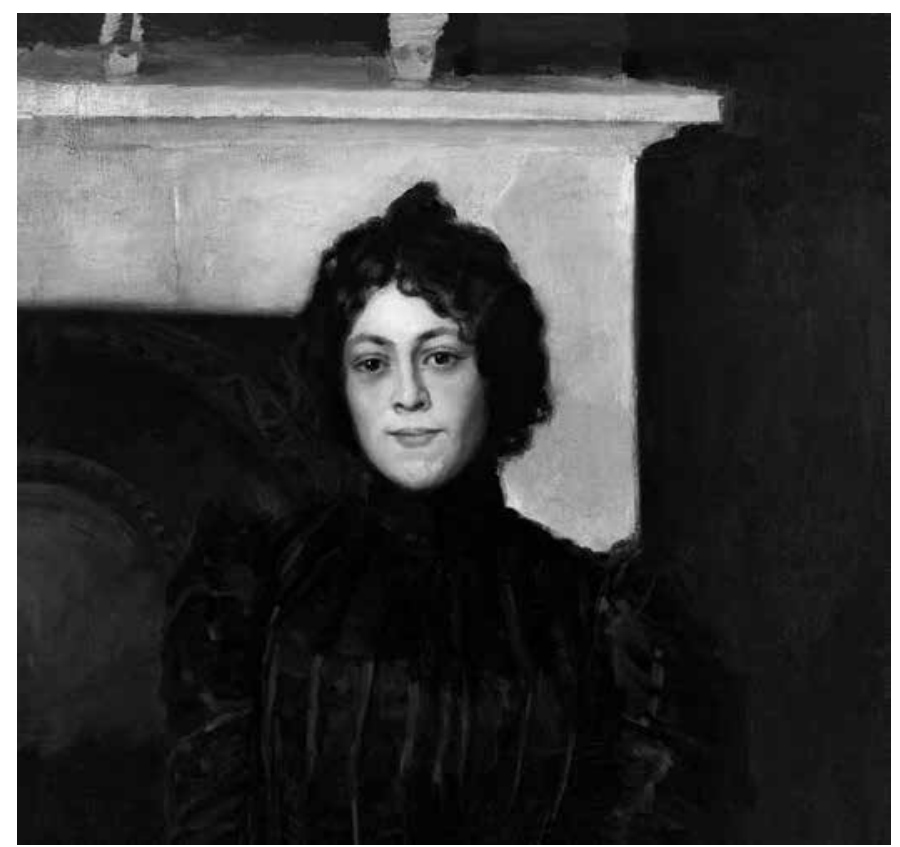

Kazimieras STABRAUSKAS. Tamsiaplaukès moters portretas. 1898

Drobė, aliejus, $64 \times 68$. „Iš Lietuvos meno pažinimo centro Tartle" kolekcijos

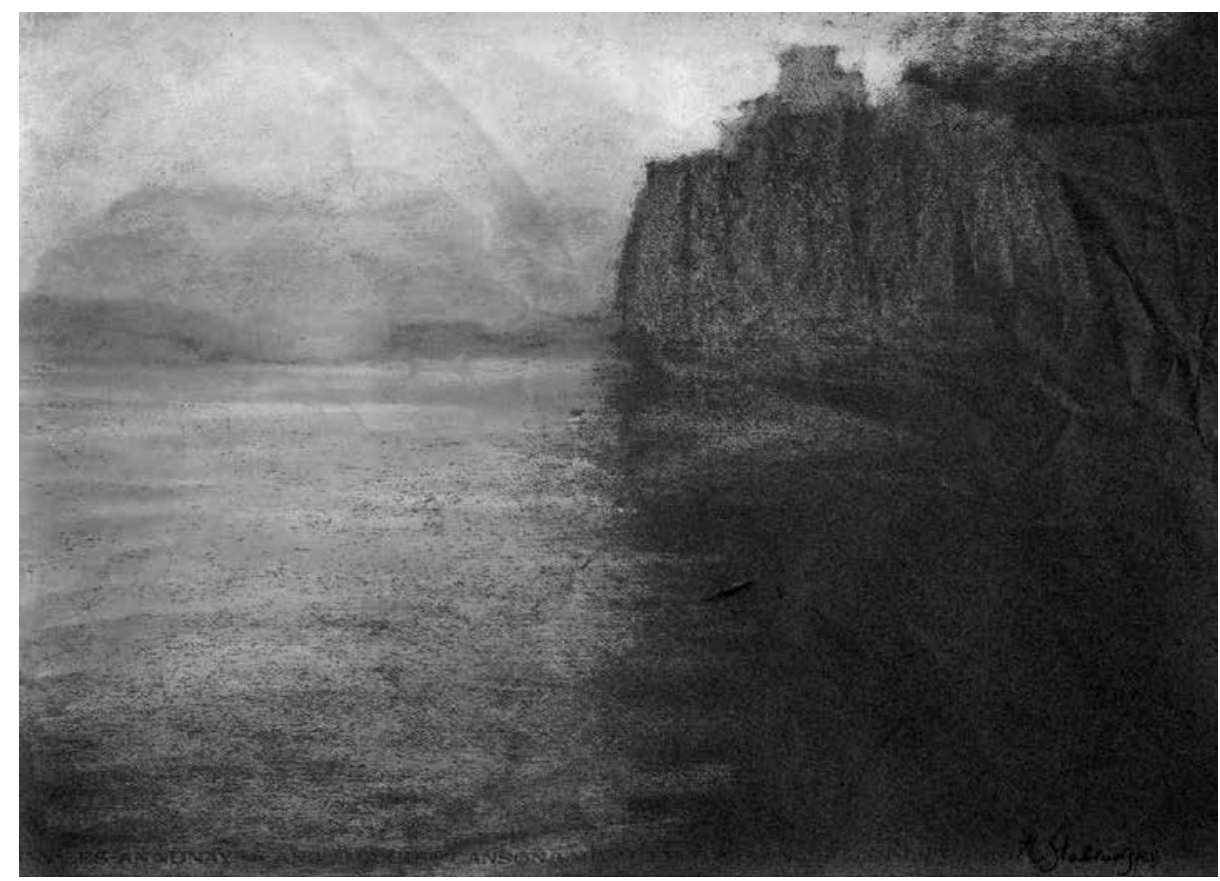

Kazimieras STABRAUSKAS. Prieaušris. Kalnas vandenyne. 1913. $47 \times 65$

Popierius, pastelè. Dr. Jauniaus Gumbio kolekcija 


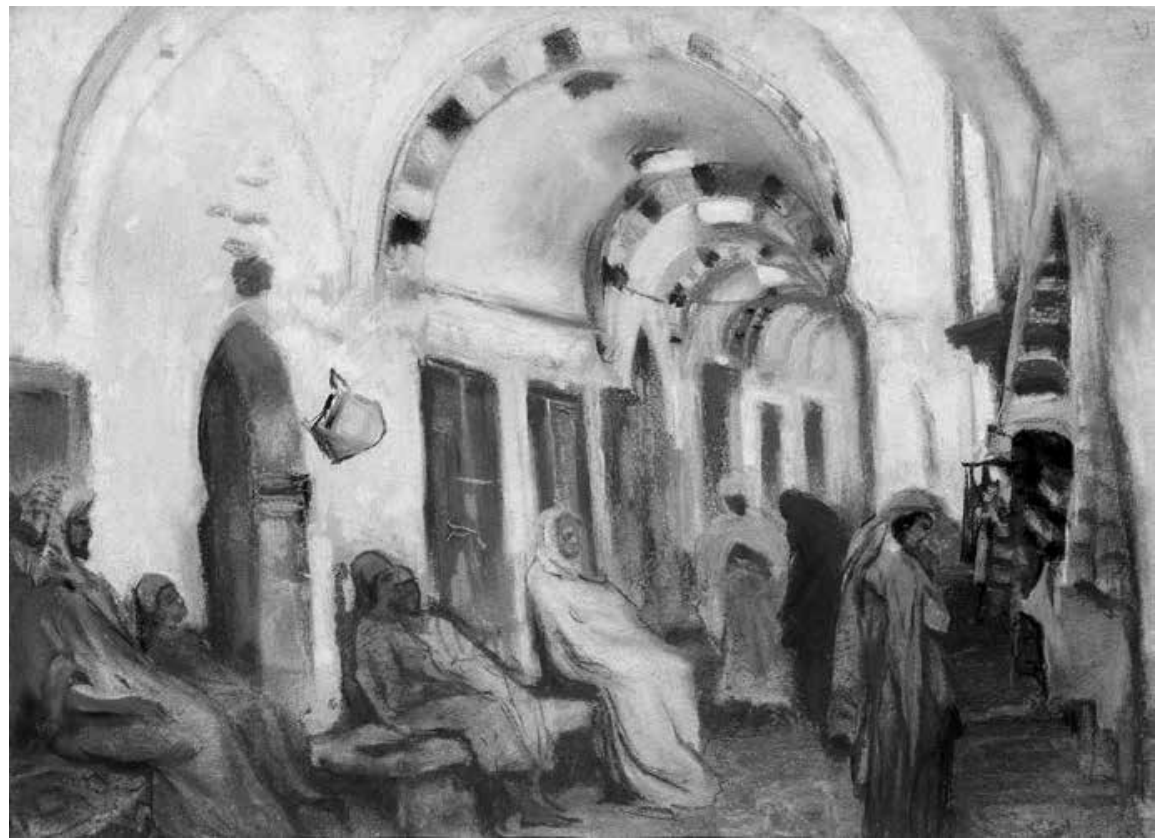

Kazimieras STABRAUSKAS. Dengtas turgus Tunise. 1894-1895. $48 \times 66$. Popierius, pastelè Iš „Lietuvos meno pažinimo centro Tartle“ kolekcijos

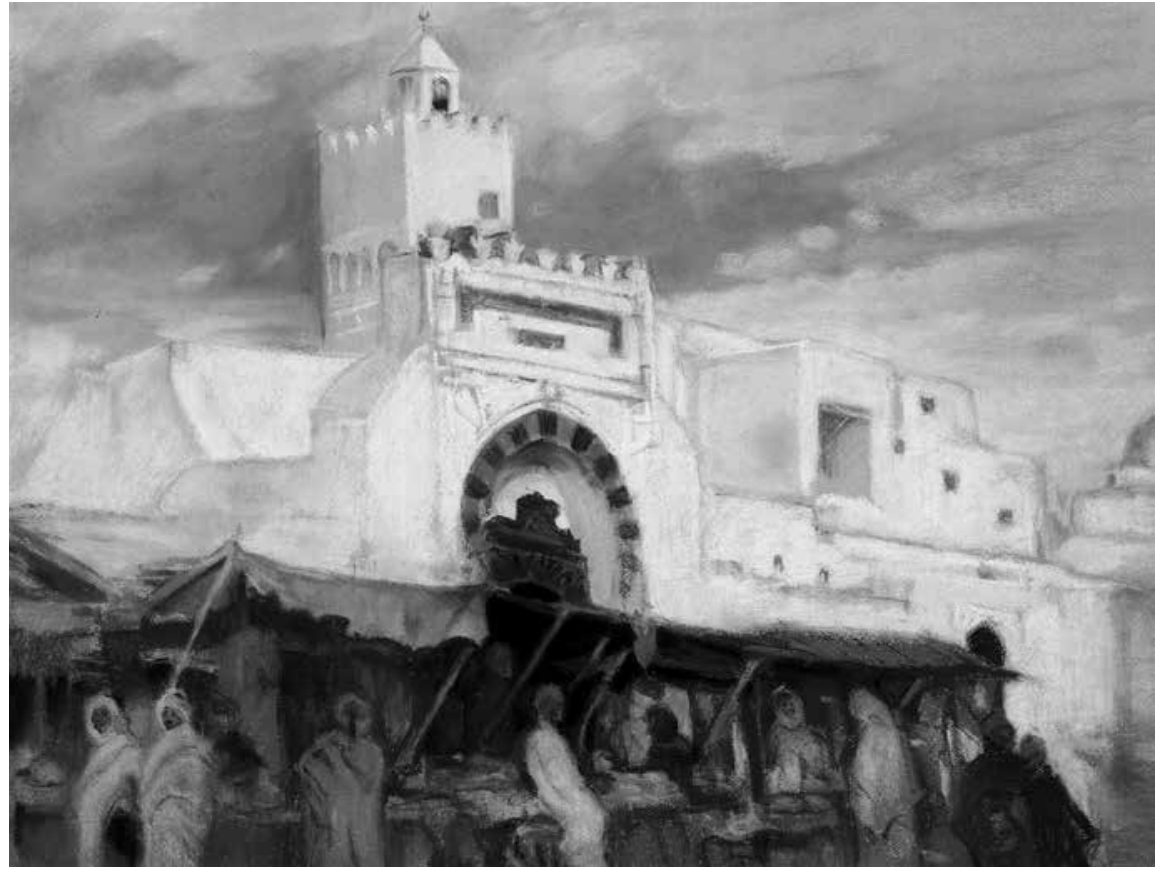

Kazimieras STABRAUSKAS. Prekyvietè. 1915. 48,5 × 65. Popierius, pastelè Dr. Jauniaus Gumbio kolekcija 